\title{
Entrepreneurship indicators, policies and their influence on the business environment in West Africa
}

\begin{tabular}{|c|c|}
\hline \multicolumn{2}{|c|}{$\begin{array}{l}\text { Authors: } \\
\text { Akinseye U. Olowu }{ }^{1} \text { (D) } \\
\text { Edwin ljeoma }{ }^{2} \text { (D) } \\
\text { Annabel Vanroose }^{1} \text { (D) }\end{array}$} \\
\hline \multicolumn{2}{|c|}{$\begin{array}{l}\text { Affiliations: } \\
{ }^{1} \text { Stellenbosch Business } \\
\text { School, Faculty of Economic } \\
\text { and Management Sciences, } \\
\text { Stellenbosch University, } \\
\text { Cape Town, South Africa }\end{array}$} \\
\hline \multicolumn{2}{|c|}{$\begin{array}{l}{ }^{2} \text { School of Government } \\
\text { and Public Administration, } \\
\text { University of Fort Hare, } \\
\text { Bhisho, South Africa }\end{array}$} \\
\hline \multicolumn{2}{|c|}{$\begin{array}{l}\text { Corresponding author: } \\
\text { Akinseye Olowu, } \\
\text { seye_olowu@yahoo.com }\end{array}$} \\
\hline \multicolumn{2}{|c|}{$\begin{array}{l}\text { Dates: } \\
\text { Received: } 29 \text { July } 2019 \\
\text { Accepted: } 25 \text { June } 2020 \\
\text { Published: } 26 \text { Nov. } 2020\end{array}$} \\
\hline \multicolumn{2}{|c|}{$\begin{array}{l}\text { How to cite this article: } \\
\text { Olowu, A.U., ljeoma, E. \& } \\
\text { Vanroose, A., 2020, } \\
\text { 'Entrepreneurship indicators, } \\
\text { policies and their influence } \\
\text { on the business environment } \\
\text { in West Africa', Africa's Public } \\
\text { Service Delivery and } \\
\text { Performance Review 8(1), } \\
\text { a345. https://doi.org/ } \\
\text { 10.4102/apsdpr.v8i1.345 }\end{array}$} \\
\hline \multicolumn{2}{|c|}{$\begin{array}{l}\text { Copyright: } \\
\text { (C) 2020. The Authors } \\
\text { Licensee: AOSIS. This } \\
\text { is licensed under the } \\
\text { Creative Commons } \\
\text { Attribution License. }\end{array}$} \\
\hline \multicolumn{2}{|l|}{ Read online: } \\
\hline apsin: & $\begin{array}{l}\text { Scan this QR } \\
\text { code with your } \\
\text { smart phone or } \\
\text { mobile device } \\
\text { to read online. }\end{array}$ \\
\hline
\end{tabular}

Background: This article examined the performance of entrepreneurship indicators and their influence on the business environments through economic rankings in selected Anglophone and Francophone countries in West Africa.

Aim: An institutional framework for entrepreneurship indicators was adopted as a measure for entrepreneurship in the region focusing on its determinants, impacts and outcomes.

Setting: The colonial policy of indirect rule in the Anglophone West Africa focused on economic development and national integration, while the colonial policy of assimilation in the francophone focused on trade and centralisation.

Method: This study focused on a comparative evaluation and synthesis.

Results: The study found that the Anglophone countries were more entrepreneurship enhancing than the Francophone divide, but the economies in the region were all factor driven.

Conclusion: The study recommends private sector partnership in the drive to promote entrepreneurship so that the entrepreneurship drive in the countries aim towards innovative and efficient competitiveness.

Keywords: entrepreneurship; anglophone; francophone; performance; West Africa.

\section{Introduction}

This article investigates entrepreneurship indicators on the business environment in anglophone and francophone West African countries using descriptive statistics. A comparative analysis of the suitability of business environment for entrepreneurship in countries is also presented. Similar studies by Cecchetti (2002), Atkeson and Kehoe (2007) and Murdock (2009) focused on the transformation of economies from managed to entrepreneurial structure. The studies emphasised the need to encourage greater opportunities for increased entrepreneurship development in countries. Distinguishing between the two types of structures in countries, they reiterated that managed economies are entrepreneurshipinhibiting, whilst those with entrepreneurial structures are entrepreneurship-encouraging. However, Kritikos (2014) supported that:

$[E]$ trepreneurship is the engine of economic change, the generator of economic growth, and the main cause of job creation. Consequently, policy is often used in different ways to support entrepreneurs to thereby create benefits from the positive effects of entrepreneurship. (p. 8)

On the other hand, William Baumol theory in Mccaffrey (2018) identified that the outcome of entrepreneurship is not necessarily productive and a boom to the economy. Rather, entrepreneurship performance can be both productive and unproductive, or even destructive depending on the institutional framework in which it takes place.

Regional entrepreneurship differentials emerged because of the spatial and place-based nature of three underlying factors: first, the nature of markets; second, the nature of innovation systems; and third, the nature of place-based cultures, communities and the institutions they establish (Huggins, Morgan \& Williams 2015). The Economic Community of West African States (ECOWAS) is the regional economic union of West Africa. Economic Community of West African States comprises two sub-regional blocs: the West African Economic and Monetary Union (WAEMU) (also known as Union économique et monétaire ouest-africaine [UEMOA] in French-speaking countries, which is limited to the eight, mostly francophone, countries that employ the CFA franc as their common currency) and the West African Monetary Zone (WAMZ), which comprises English-speaking countries of West Africa working towards adopting their own common currency, 
that is, the Eco. Economic Community of West African States' Vision 2020 strategy aims to develop the region by harmonising sectoral policies across countries (https:// www.ecowas.int/about-ecowas/vision-2020/). Although the classification of countries based on the colonial history in this study seems static, it is not subject to changes or transformations. However, it serves as a justification for grouping the countries in order to measure their entrepreneurship performance.

\section{The anglophone West Africa}

The national objectives of governments in the anglophone West African countries are rapid economic development and national integration. The pursuit of these objectives guarantees modernisation and political participation in this process from the village to the national level. Modernisation means the progressive organisation of societies at the national level. The analysis of modernisation by Hopkins (1973) provides a theoretical framework for the consideration of governmental process, which itself involves the formulation and implementation of policies designed to achieve government objectives, which invariably revolve around modernisation. The most important purpose of government in developing countries, apart from the maintenance of law and order and economic development, is national integration. This most formidable task of government arises from the lack of cohesion and national framework for guaranteeing this before the advent of colonialism. Although colonial boundaries are artificial, they have nevertheless provided the necessary geographical horizon, which is important for the purpose of national political organisation and integration.

\section{The francophone West Africa}

Like the other foreign powers that came to West Africa, the initial interest of the French was trade. From the time French presence was first established in Saint Louis (Senegal) in 1637 until the middle of the 19th century, successive French Governments were almost exclusively concerned with the development of fortified trading posts along the Rivers Senegal and Upper Niger and at different points on the coast. To this end, they signed treaty agreements with the indigenous populations. The organisation of the administration in French West Africa was regulated by these decrees. In matters of detail, the Governor General could issue orders (arretes), which had to be consistent with the provisions of the decrees. The most outstanding features of the administrative arrangements for the divide were its unitary character and a high degree of centralisation. The high degree of centralisation was because of the concentration of administrative activities at the federal centre. However, in 1890, 'the policy of assimilation' was sanctioned as the official policy in all French colonies including those in French West Africa. The idea of assimilation as a colonial policy is commonly traced back to the egalitarian ideas of the 1789 French Revolution. In 1794,
TABLE 1: The differences within West Africa.

\begin{tabular}{|c|c|c|c|}
\hline Number & Colonial differences & Anglophone & Francophone \\
\hline 1 & Language & English & French \\
\hline 2 & Currency & $\begin{array}{l}\text { Individual currencies } \\
\text { exist in each county }\end{array}$ & $\begin{array}{l}\text { Common CFA hedged to } \\
\text { the franc }\end{array}$ \\
\hline 3 & Colonialist & Great Britain & France \\
\hline 4 & $\begin{array}{l}\text { International } \\
\text { affiliations }\end{array}$ & $\begin{array}{l}\text { Common wealth of } \\
\text { Nations }\end{array}$ & $\begin{array}{l}\text { International } \\
\text { Organization of La } \\
\text { Francophonie }\end{array}$ \\
\hline 5 & Colonial ideology & Policy of indirect rule & Policy of assimilation \\
\hline 6 & $\begin{array}{l}\text { Regional capital } \\
\text { market }\end{array}$ & $\begin{array}{l}\text { No joint stock exchange } \\
\text { but exists in individual } \\
\text { countries }\end{array}$ & $\begin{array}{l}\text { BRVM operating across } \\
\text { French West African } \\
\text { Economic and Monetary } \\
\text { Union (WAEMU) }\end{array}$ \\
\hline 7 & Number of countries & 5 & 11 \\
\hline
\end{tabular}

BVRM, Bourse Regionale des Valeurs Mobilieres.

the revolutionary government issued a proclamation according to which all people residing in France and the empire were entitled to French citizenship. However, besides this laudable egalitarian principle, the French also sought, through the policy of assimilation, to assert the superiority of French culture, which they believed was superior to all others. In the case of the colonies in Africa, a cultural void existed. The implementation of the assimilation policy started in Senegal, which was the first French colony in West Africa.

\section{The differences within West Africa}

Following the aftermath of colonialism, which swept across Africa, the policy of indirect rule in the anglophone West Africa focused on economic development and national integration, whilst the policy of assimilation in the francophone West Africa focused on trade and centralisation. Britain controlled The Gambia, Sierra Leone, Ghana and Nigeria throughout the colonial era, whilst France unified Senegal, Guinea, Mali, Burkina Faso, Benin, Cote D'Ivore and Niger into French West Africa. Portugal founded the colony of Guinea-Bissau, whilst Germany claimed Togoland, but was forced to divide it between France and Britain following the First World War. These conditions are responsible for the differences highlighted in Table 1:

Basically, the broad trade-offs within the two divides in West Africa are the difference of colonial master, language, membership of unions, currency and, of particular interest to this study, the existence of the capital market in the francophone countries, which have developed steadily over the years evidenced by the establishment of Bourse Regionale des Valeurs Mobilieres (BRVM), ${ }^{1}$ physically located in Cote D'Ivore, which serves the countries of the WAEMU. Although the market remains relatively small and illiquid, the researchers' objective was to determine the entrepreneurial competitiveness of the divides taking equity portfolio into consideration as one of the measures of institutional entrepreneurship. According to North (1981) and Jones (1981), countries with efficient institutions and less distortionary policies will achieve a greater level of income. For instance, could the dependency of the central banks in 1.BVRM is a regional stock market serving the countries of the West African Economic and Monetary Union (WAEMU). It is physically located in Abidjan - Côte d'Ivoire. 
the francophone countries or the independency of the anglophone countries make or mar entrepreneurship? Perhaps this factor may enhance entrepreneurship in the francophone divide given the operations of the regional market in existence. This notion could be corroborated by the dictates of structural economics approach, ${ }^{2}$ which presumes that financial markets enhance development ${ }^{3}$ in economies.

\section{The entrepreneurship indicators}

Entrepreneurship is understood to mean the process of enhancing entrepreneurial activities often linked to economic growth, which makes its performance measureable. It is also the 'influences' and 'characteristics of entrepreneurial behaviour' leading to innovation, creativity and adding value (Hornby 2010). Based on previous studies, some of the indicators used to assess entrepreneurship performance were derived from the Global Entrepreneurship Monitor (GEM). Further, based on other studies done on measures and drivers of the knowledge economy, in the reports of technology and innovation foundation in Bergmann et al. (2013), Murdock (2009), Saisana and Munda (2008), Atkinson and Correa (2007) and Allen (2001), the indicators were categorised into four groups, namely globalisation measures, technology innovation capacity measures, economic dynamism measures and digital economy measures.

The recognition of entrepreneurship as a driver of economic growth has led policy analyst, researchers and economic theoreticians improve on the measurement of entrepreneurship at national level. For instance, at an international level, programs by the World Bank, Eurostat and private organisations such as GEM have developed an internationally comparable data (Ahmad \& Hoffman 2007). Hence, the entrepreneurial indicators in countries were adopted from the framework. However, it is impossible to adopt the full indicators of entrepreneurship as measured by previous studies, GEM and the knowledge economy indicators. ${ }^{4}$ Therefore, we adopt a specific entrepreneurship indicator at country level for the study using Organisation for Economic Co-operation and Development (OECD) indicators in Ahmad and Hoffman (2007) along with some indicators of GEM and knowledge economy as follows:

RD \& technology: This variable determines entrepreneurship competence. It represents science and technology research in countries, which brings about innovation. Innovation has been argued to be an inventive entrepreneurial process, which creates new economic value (Hindle 2009).

2.Structuralist economy measures the policies by identifying specific rigidities and lags as well as other characteristics of the structure of developing countries (Dutt \& Ros 2003).

3.Bearing in mind that economic development comprises entrepreneurship according to Joseph Schumpeter's (1934) theory of economic development.

4.A knowledge economy is an economy driven by science and technology in the pursuit of innovation.
The variable has been found to be the driving force behind the growth in scientific and economic communities. There should be a high correlation between science and technology researches and an entrepreneurial economy. In the wake of globalisation, entrepreneurs depend on new research findings to improve on their old ways of production and service delivery. Research remains the invisible hand behind much of the development in countries. Entrepreneurs are not often the ones who carry out the researches; they just spot an opportunity in scientific research and synthesise it to a business (Aderemi et al. 2013).

Revenue from export: This is the income realised from the exportation of creativity and innovativeness within the economy. Revenue from export indicates that entrepreneurship activities exist in a country. It shows that locally produced goods not only are patronised internally but also are enough to be sold to the international market. Exportation enhances the economy that aligns with the government goal of economic growth (Adesoji \& Sotubo 2013; Abou-Strait 2005). An increase of this variable in countries is an indication that the economy is an entrepreneurship outcome.

Domestic private investment: This measures the rate of investment in the private sector. It is an indication of the existence of well-performing firms, healthy enough to attract investors despite the risk associated with investment. The rate of domestic private investment also signifies that there are sound investment-friendly policies capable of attracting investors (Akpokodje 1998; Dehn 2000; Greenaway \& Morrissey 1992; Harrigan \& Mosely 1991; Khan \& Reinhart 1990; Lemi \& Asefa 2001; Serven \& Salimano 1992). This variable is represented by the gross fixed capital formation of the private sector in countries. It is an entrepreneurship outcome.

Equity portfolio/stocks: As a result of the emerging trend of the region's stock exchange markets in West Africa, this was deemed fit as a variable for measuring entrepreneurship. More so, capital markets contribute to the economic growth in studies (Adjasi \& Biekpe 2006; Beck \& Levine 2004; Enisan \& Olufisayo 2009; Ezeoha, Ogamba \& Onyiuke 2009; N'zue 2006). This is because liquidity is the means by which entrepreneurship activities are financed. Liquid markets attract savings and also encourage long-term investment in projects that have high return on investment. The variable is an entrepreneurship outcome.

Economic growth: This is a measure of the economic output or domestic productivity of a country divided by the total number of people in the country. It is the best measure of standard of living. The variable explains the outcomes of entrepreneurship in the economy. If the standard of living is high, it partly explains that there are productive entrepreneurship activities going on in the economy. According to literature, high growth in real gross domestic 
product (GDP) per capita signifies increased entrepreneurship outcomes (Audretsch, Lehmann \& Keilbach 2006).

Job creation: This is a measure of self-employed workers, specifically those workers who are self-employed or small and medium entrepreneurs who own their businesses with one or a few partners. According to Awe (2010), entrepreneurship is the task of increasing the supply of manpower capable of undertaking business creation, which accelerates employment generation. Studies by Carree and Thurik (2002) and the Organisation for Economic Co-operation and Development (OECD) (1998) have also used data on self-employment as one of the indicators of entrepreneurial activities.

\section{Methodology}

The approaches to policy performance evaluation refer to the platforms for which policy can be measured. Policy can best be accessed through its output, impact and outcomes (Rosenbloom, Kravchuk \& Clerkin 2009). These three main measures, although related, have distinct features that explain the performance context this study set out to determine. Policy performance can be investigated through its outputs or the impacts of the particular policy. Countries make use of a number of methods comprising mainly qualitative and quantitative approaches to decipher the performance of their public policies. The evolution of policy analysis in the Netherlands, as narrated by Mayer (2007), is a typical example of empirical policy analysis. The study attempted to analyse and interpret the evolution of policy analysis in the country by questioning factors used in policy comparison over time. Netherlands is part of the European Union policy area in respect of finance, development cooperation, transport, security and agriculture. Just as this study focused on the colonial history of West Africa divides, the study by Mayer (2007) made references to the historical background of the formation of the public policies in the country and how they compared to other developed countries of the world such as the United States and the United Kingdom (Bernelmans-Videc 1994). The descriptive statistics explored summarises and presents the entrepreneurship indicators in a convenient way that aids understanding of the performance.

In order to ascertain the performance, the study made use of 10 countries as its sample which comprises five anglophone and five francophone countries in West Africa. The 10 countries used were: The Gambia, Ghana, Liberia, Nigeria, Sierra Leone, Cote D'Ivore, Mali, Burkina Faso, Senegal and Benin. These countries were purposively selected in the divides based on the hierarchy of their GDP performance figures as of 2017. The aim of the statistics presented is to determine the performance of the entrepreneurship indicators in anglophone and francophone West African countries, through comparative measures in order to establish public policy gaps. According to Ijeoma (2014), an evaluation systematically assesses programmes or policies in order to summarise the presentation of a given data set. Evaluation also refers to the process of determining the worth or significance of an activity, policy or programme. The focus here accounts for the progress, status, rankings, development, causes, implementation, consequences and problems of public policies.

\section{Descriptive statistics of entrepreneurship indicators in anglophone and francophone West Africa}

These descriptive statistics are illustrated in the following figures (Figures 1 to 6), with each including the statistics of both the anglophone and francophone divides.

From Figure 1, it is evident that the anglophone West African countries perform better than the francophone ones. Nigeria ranked high at the determinant, whilst the francophone countries were ranked low. The Gambia, Sierra Leone and Liberia also ranked low in the science and technology measure of entrepreneurship determinant. The figure represents the number of scientific and engineering articles published in journals. This figure is determinant on the amount of universities and

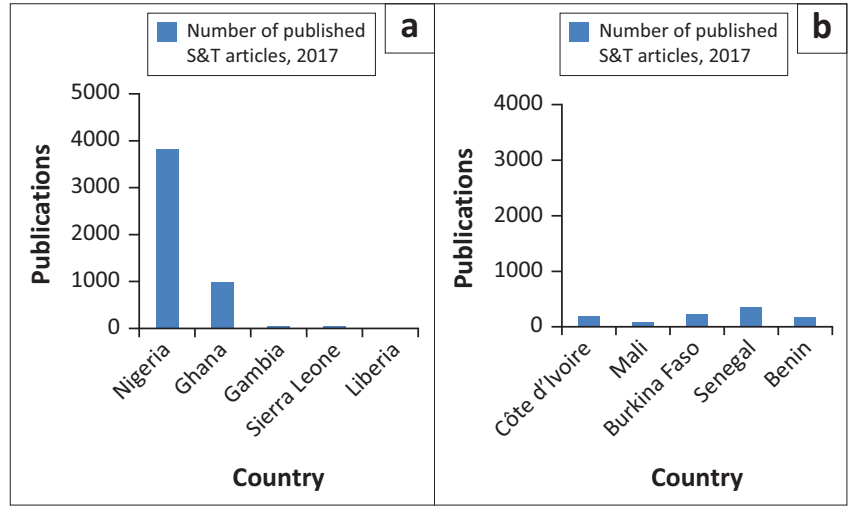

Source: World Development Indicators (WDI), n.d., World Development Indicators, viewed 20 May 2019, from https://databank.worldbank.org/source/world-development-indicators S\&T, science and technology; R\&D, research and development.

FIGURE 1: Entrepreneurship determinant as a component in entrepreneurship indicators: R\&D and Technology: (a) anglophone: R\&D, science and technology, (b) francophone: R\&D, science and technology.

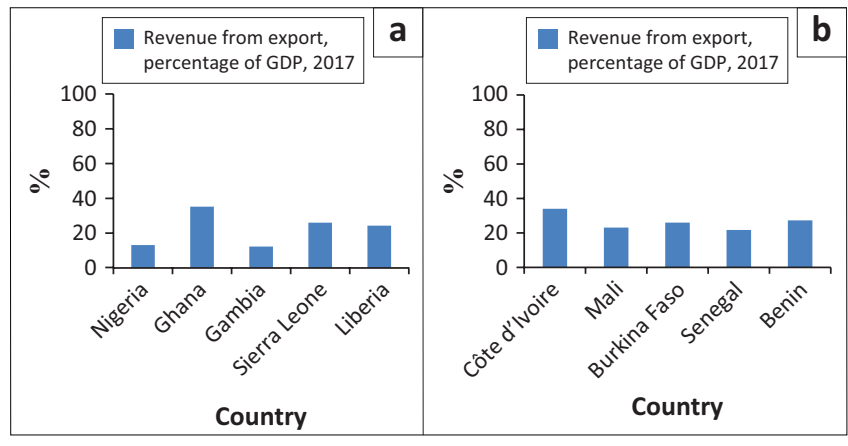

Source: World Development Indicators (WDI), n.d., World Development Indicators, viewed 20 May 2019, from https://databank.worldbank.org/source/world-development-indicators GDP, gross domestic product.

FIGURE 2: Entrepreneurship outcome as a component in entrepreneurship indicators: (a) anglophone: revenue from export, (b) francophone: revenue from export. 
researchers in countries. All the countries in West Africa have their own university system. However, access to tertiary education is unevenly distributed in the region, hence the lopsidedness of this indicator in the anglophone divide where there are more private sector participation in the tertiary education sector. Nevertheless, regional collaboration is essential to tackling regional development challenges and promoting entrepreneurship.

From Figure 2, it is evident that both divides have competed fairly closely as the revenue each received were at par except for Ghana that received the most revenue from export in the year reviewed. According to Boame (1998), the primary-export-led growth strategy in Ghana sets the anglophone country at a pace to increase its export promotion performance. However, export trade across West African states have been reported as low, largely informal, poorly documented and believed to be dominated by staple food. Yet, it has considerable potential to increase, in line with ECOWAS ambitions (Torres \& Seters 2016). The revenue from export represents the value of all goods and other market services provided to the rest of the world.

From Figure 3, it is evident that domestic private investments are relatively low in both divides. For the same reasons

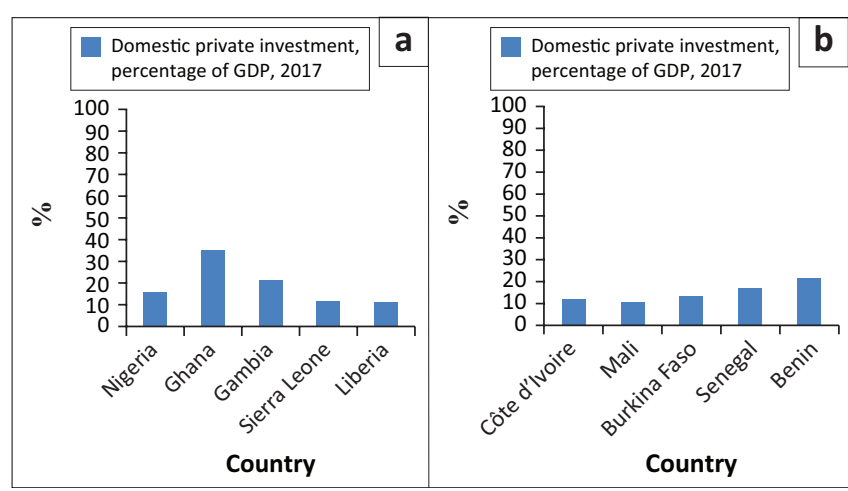

Source: World Development Indicators (WDI), n.d., World Development Indicators, viewed 20 May 2019, from https://databank.worldbank.org/source/world-development-indicators FIGURE 3: Entrepreneurship outcome as a component in entrepreneurship indicators: (a) anglophone: domestic private investment, (b) francophone: domestic private investment.

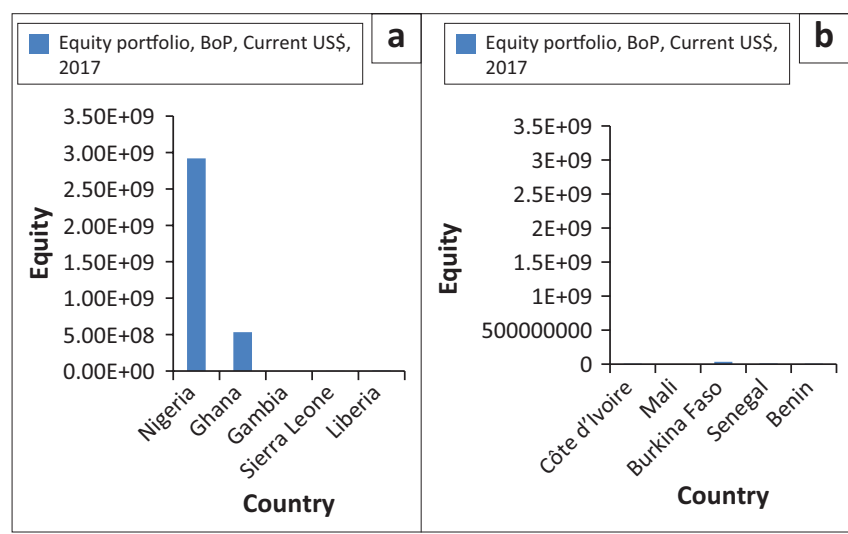

Source: World Development Indicators (WDI), n.d., World Development Indicators, viewed 20 May 2019, from https://databank.worldbank.org/source/world-development-indicators FIGURE 4: Entrepreneurship outcome as a component in entrepreneurship indicators: (a) anglophone: equity portfolio; (b) francophone: equity portfolio. stated in Figure 2 by Torres and Seters (2016), there have been minimal investments, which signify that the incentives directed towards the private sector in which a sizeable number of entrepreneurship activities take place need to be reviewed.

Despite the regional stock exchange (BRVM) in the francophone countries, the chart shows that their operations have not been commendable. This is because the stock market has been illiquid (Agyapong 2014). The occurrence of such situations inhibits entrepreneurship activities as it reflects low net inflows from equity securities including shares, stocks, depository receipts and direct purchases of shares in local stock markets by foreign investors. However, the policy regulating the financial sector in Nigeria has been entrepreneurship-enhancing in encouraging equity portfolios.

Economic growth is a measure of entrepreneurship performance. Nigeria had the highest in the anglophone divide, whilst Côte d'Ivoire had the highest in the francophone divide. This signifies domestic production of goods, which is a function of creativity, innovation and adding value that appropriately describes entrepreneurship

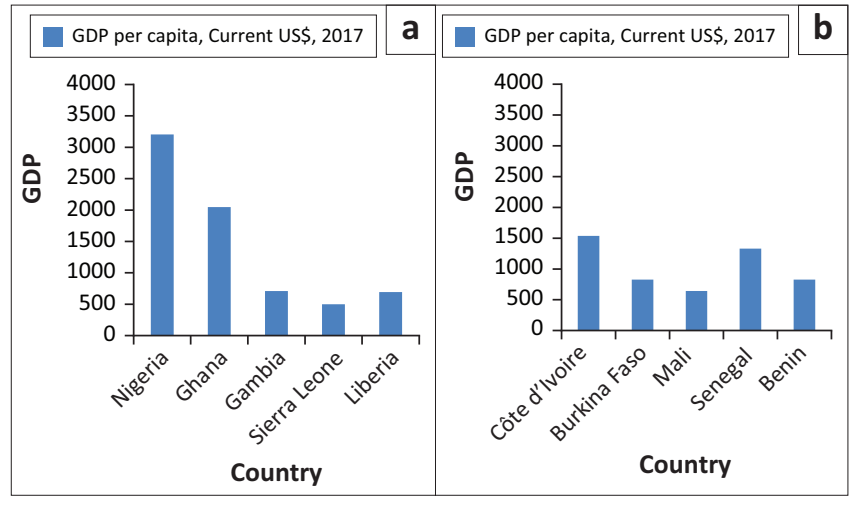

Source: World Development Indicators (WDI), n.d., World Development Indicators, viewed 20 May 2019, from https://databank.worldbank.org/source/world-development-indicators GDP, gross domestic product.

FIGURE 5: Entrepreneurship impact as a component of entrepreneurship indicator: (a) anglophone: Economic growth, (b) francophone: economic growth.

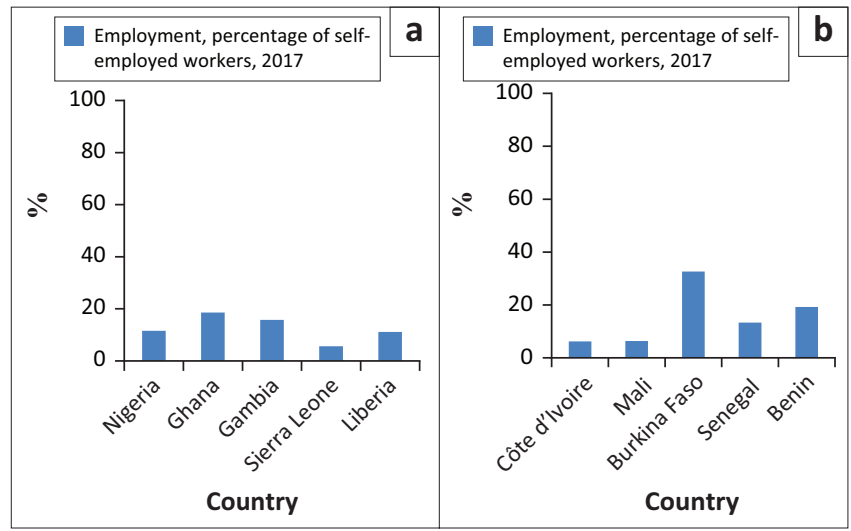

Source: World Development Indicators (WDI), n.d., World Development Indicators, viewed 20 May 2019, from https://databank.worldbank.org/source/world-development-indicators FIGURE 6: Entrepreneurship impact as a component in entrepreneurship indicators - Job creation (a) anglophone; (b) francophone. 
activities. Overall, the anglophone divide had a higher total GDP per capita compared to their counterpart.

\section{The Comparative evaluation of the business environment in West Africa}

This presents a clear focus on the systematic, comparative study of the business environment in countries. For this study, the purpose of evaluating the business environment in countries was to determine how favourable they are for the purpose of entrepreneurship activities by making references to the ranking reports and ratings of global institutions, such as the Global Entrepreneurship Monitor, Ibrahim Index of African Governance and Index of Economic Freedom. Thus, the evaluation was based on the designed score ranking of the business environments: $0=$ not too accommodative, 1 = accommodative, 2 = encouraging, 3 = most ideal for entrepreneurship activities.

From Table 2, an evaluation was made based on four institutional observations of public policies and their implication on entrepreneurship in the business environment. The monetary and the fiscal policies are controlled by the government in the five West African countries through their independent central banks. The Ibrahim Index of African Governance evaluates the effect of monetary and fiscal policies on the business environment. The regulatory efficiency is measured by the Index of Economic Freedom as the condition of the economic environment over which governments typically exercise policy control. It focuses on the effect of government policies on Business Freedom, Government Spending and Monetary Freedom. These three measures determine the conduciveness of entrepreneurship in national context. The efficiency is scored when there is an increase from the previous year's performance compared to 2018 figures, such as indicated with $\uparrow$ symbol. Under the 'Entrepreneurship Evaluation', in countries where:

- One $\uparrow$ denotes that the policies inherent are 'accommodative' for entrepreneurship activities.

- Two $\uparrow$ denotes that the policies inherent are 'encouraging' for entrepreneurship activities.

- Three $\uparrow$ denotes that the policies inherent are 'most ideal' for entrepreneurship activities.

- Whilst '- ' denotes no change from previous performance.

Lastly, the 'National Economic Environment' is ranked by the Global Entrepreneurship Monitor data according to the World Economic Forum (WEF) in its global competitiveness report. The Global Entrepreneurship Monitor data rate all five anglophone West African countries, namely Nigeria, Ghana, The Gambia, Sierra Leone and Liberia as 'factordriven economies'. According to the WEF's classification, factor-driven economies are the least developed, which are dominated by subsistence agriculture and extraction businesses, with a heavy reliance on (unskilled) labour and natural resources.

From Table 3, it appears that the francophone countries such as Burkina Faso and Cote D'Ivore addressed their public policy strategies such that they were ranked high in attracting business. This could be because of the regional cooperation that exists in the divide. Their policies must have focused on easing regulatory issues for starting businesses such as securing permits and cross-border business incentives. This reiterates the fact that there is no meaningful entrepreneurship development without public policy interventions.

TABLE 2: Comparative evaluation of the business environment in anglophone countries.

\begin{tabular}{|c|c|c|c|c|c|c|}
\hline Number & Country & $\begin{array}{l}\text { Summary of government economic policies } \\
\text { that can drive entrepreneurship activities } \\
\text { taking into account their focus, locus, target } \\
\text { and system of finance }\end{array}$ & $\begin{array}{l}\text { Ranking of the } \\
\text { business environment: } \\
\text { Ibrahim Index of African } \\
\text { Governance rankings }\end{array}$ & $\begin{array}{l}\text { Regulatory efficiency of } \\
\text { the policies: Economic } \\
\text { Freedom ratings }\end{array}$ & $\begin{array}{l}\text { Entrepreneurship } \\
\text { evaluation: } \\
\text { Researcher's } \\
\text { evaluation }\end{array}$ & $\begin{array}{l}\text { National economic } \\
\text { environment: Global } \\
\text { Entrepreneurship } \\
\text { Monitor ratings }\end{array}$ \\
\hline 1 & Nigeria & $\begin{array}{l}\text { To attain price stability through external reserves } \\
\text { to safeguard the international value of the legal } \\
\text { currency. The macroeconomic policies in Nigeria } \\
\text { are financed and controlled by the } \\
\text { Central Bank of Nigeria. }\end{array}$ & 34 out of 54 countries & $\begin{array}{l}\text { - Business Freedom } \\
\text { (49.3) } \uparrow \\
\text { - Government Spending } \\
\text { (96.3) } \uparrow \\
\text { - Monetary Freedom } \\
\text { (66.9) } \downarrow\end{array}$ & $33.3 \%$ Encouraging & $\begin{array}{l}\text { Factor-Driven } \\
\text { Economy }\end{array}$ \\
\hline 3 & The Gambia & $\begin{array}{l}\text { To achieve and maintain price and exchange } \\
\text { stability underpinned by a sound and vibrant } \\
\text { financial system to encourage and promote } \\
\text { sustainable economic development. The } \\
\text { macroeconomic policies in Gambia are financed } \\
\text { and controlled by the Central Bank of Gambia. }\end{array}$ & 31 out of 54 countries & $\begin{array}{l}\text { - Business Freedom } \\
\text { (54.2) } \uparrow \\
\text { - Government } \\
\text { Spending }(74.0) \downarrow \\
\text { - Monetary } \\
\text { Freedom (63.2) } \downarrow\end{array}$ & $33.3 \%$ Accommodative & $\begin{array}{l}\text { Factor-Driven } \\
\text { Economy }\end{array}$ \\
\hline 5 & Liberia & $\begin{array}{l}\text { To maintain price stability and to ensure a sound } \\
\text { banking and financial system, thereby } \\
\text { contributing to sustainable economic } \\
\text { development of the nation. The macroeconomic } \\
\text { policies in Liberia are finance and controlled by } \\
\text { the Central Bank of Liberia. }\end{array}$ & 14 out of 54 countries & $\begin{array}{l}\text { - Business Freedom } \\
\text { ( } 53.1)- \\
\text { - Government } \\
\text { Spending (59.4) } \downarrow \\
\text { - Monetary } \\
\text { Freedom (71.4) } \downarrow\end{array}$ & Not too accommodative & $\begin{array}{l}\text { Factor-Driven } \\
\text { Economy }\end{array}$ \\
\hline
\end{tabular}

Note: Researcher's evaluation based on scores ranking: $0=$ not too accommodative, $1=$ accommodative, $2=$ encouraging, $3=$ most ideal. 
TABLE 3: Comparative evaluation of the business environment in francophone countries.

\begin{tabular}{|c|c|c|c|c|c|}
\hline Number & Country & $\begin{array}{l}\text { Ranking of the business } \\
\text { environment: Ibrahim Index of } \\
\text { African Governance rankings }\end{array}$ & $\begin{array}{l}\text { Regulatory efficiency of the policies: } \\
\text { Economic Freedom ratings }\end{array}$ & $\begin{array}{l}\text { Entrepreneurship evaluation: } \\
\text { Researcher's evaluation }\end{array}$ & $\begin{array}{l}\text { National economic environment: } \\
\text { Global Entrepreneurship Monitor } \\
\text { ratings }\end{array}$ \\
\hline 1 & Cote D'Ivore & 20 out of 54 countries & $\begin{array}{l}\text { - Business Freedom }(62.1)- \\
\text { - Government Spending }(84.6)-\end{array}$ & $33.3 \%$ Accommodative & Factor-driven economy \\
\hline 2 & Mali & 25 out of 54 countries & $\begin{array}{l}\text { - Business Freedom (52.8) } \\
\text { - Government Spending (85.3) } \downarrow \\
\text { - Monetary Freedom (81.9) } \downarrow\end{array}$ & $33.3 \%$ Accommodative & Factor-driven economy \\
\hline 3 & Burkina Faso & 21 out of 54 countries & $\begin{array}{l}\text { - Business Freedom (51.5) } \\
\text { - Government Spending (83.7) } \uparrow \\
\text { - Monetary Freedom (84.5) } \downarrow\end{array}$ & $66.6 \%$ Encouraging & Factor-driven economy \\
\hline 4 & Senegal & 10 out of 54 countries & $\begin{array}{l}\text { - Business Freedom (51.5) } \\
\text { - Government Spending (72.7) } \downarrow \\
\text { - Monetary Freedom (84.7) } \downarrow\end{array}$ & $33.3 \%$ Accommodative & Factor-driven economy \\
\hline 5 & Benin & 14 out of 54 countries & $\begin{array}{l}\text { - Business Freedom (60.7) } \\
\text { - Government Spending (85.6) } \downarrow \\
\text { - Monetary Freedom (84.7) } \downarrow\end{array}$ & $33.3 \%$ Accommodative & Factor-driven economy \\
\hline
\end{tabular}

Note: Summary of government economic policies that can drive entrepreneurship activities -taking into account their focus, locus, target and system of finance: The Primary objective of monetary policy in the French West African countries is to ensure price stability without prejudice to this objective. The macroeconomic policies in the countries are financed and controlled by the Central Bank of West African States otherwise known as Banque Centrale des États de l'Afrique de l'Ouest (BCEAO). The central bank serves the eight west African countries that share the common West African CFA franc currency and comprises the West African Economic and Monetary Union (WAEMU). The bank also supports the economic policy of the WAEMU for a healthy and sustainable growth.

\section{Conclusion}

This article considered entrepreneurship indicators in West Africa bearing elements of varying competitiveness in the pursuit of entrepreneurship development. Basically, the broad trade-offs between anglophone and francophone countries are the difference of colonial master, language, membership of unions, currency and, of particular interest to this study, the existence of the capital market in the francophone countries which have developed steadily over the years evidenced by the establishment of BRVM. Although the market remains relatively small and illiquid, the study's objective was to determine the entrepreneurial competitiveness of the divides taking equity portfolio into consideration as one of the measures of institutional entrepreneurship. According to North (1981) and Jones (1981), countries with efficient institutions and less distortionary policies will achieve a greater level of income. For instance, could the dependency of the central banks in the francophone countries or the independency of the anglophone countries make or mar entrepreneurship? Perhaps this factor may enhance entrepreneurship in the francophone divide given the operations of the regional market in existence. This notion is supported by the dictates of the structural economics approach (Dutt \& Ros 2003), which presumes that financial markets enhance development (Schumpeter 1934) in economies.

From the descriptive statistics, the anglophone divide ranks higher than the francophone divide under the 'entrepreneurship determinant' category. Whilst the anglophone divide performs better under the 'entrepreneurship outcome' category, countries within the francophone divide received more returns from exported goods. The data used show that Burkina Faso ranks highest in job creation criteria whilst the anglophone divide's economic growth is cumulatively higher than that of the francophone divide under the 'entrepreneurship impact' category. However, based on the overall entrepreneurship indicator performance, the efforts of the francophone divide seem uniformed across the countries. The common currency, the common central bank, that is BCEAO, and the regional capital market, that is $B R V M$, could be instrumental to the uniformity of performance across the countries. The cluster analysis shows that the anglophone divide has a cumulative higher mean of the entrepreneurship indicators than the francophone divide which signifies that the anglophone countries were entrepreneurship-enhancing, whilst the francophone countries were entrepreneurship-inhibiting during the period reviewed. The comparative analysis of the business environment using various economic rankings shows that both divides operate within a factor-driven economy whereby economic sustainability is heavily reliant on subsistence agriculture, extraction business, unskilled labour and natural resources. Rather, countries are supposed to be efficiency- and innovation-driven in order to attract more entrepreneurship activities (Global Entrepreneurship Monitor [GEM] 2010).

\section{Acknowledgements Competing interests}

The authors have declared that no competing interests exist.

\section{Authors' contributions}

E.I and A.V. were the supervisors of the $\mathrm{PhD}$ thesis from which the manuscript was derived. A.U.O was the doctoral candidate responsible for writing the introduction, methodology, evaluation and synthesis from other countries. E.I. and A.V. perused the conclusion and recommendations.

\section{Ethical consideration}

This article followed all ethical standards for carrying out research without direct contact with human or animal subjects.

\section{Funding information}

This research received no specific grant from any funding agency in the public, commercial or not-for-profit sectors. 


\section{Data availability statement}

Data sharing is not applicable to this article as no new data were created or analysed in this study.

\section{Disclaimer}

The views and opinions expressed in this article are those of the authors and do not necessarily reflect the official policy or position of any affiliated agency of the authors.

\section{References}

Abou-Strait, F., 2005, Are exports the engine of economic growth? An application of cointegration and causality analysis for Egypt, 1977-2003, Economic Research Working Paper, African Development Bank, Egypt.

Aderemi, H.O., Hassan, O.M., Siyanbola, W.O. \& Taiwo, K., 2013, 'Trends in enrollment, graduation and staffing of science and technology education in Nigeria tertiary institutions: A gender participation perspective', Educational Research and Reviews 8(21), 2011-2020.

Adesoji, A.A. \& Sotubo, O.D., 2013, 'Non-oil exports in the economic growth of Nigeria: A study of agricultural and mineral resources', Journal of Educational and Social Research 3(2), 403-418.

Adjasi, C.K.D. \& Biekpe, N.B., 2006, 'Stock market development and economic growth: The case of selected African countries', African Development Review 18(11), 144-161. https://doi.org/10.1111/j.1467-8268.2006.00136.x

Agyapong, D., 2014, 'Stock market integration in West African Monetary Zone: A linear and nonlinear cointegration approach', Asian Economic and Finance Review 4(5), 563-587.

Ahmad, N. \& Hoffman, A., 2007, A framework for addressing and measuring entrepreneurship, Entrepreneurship Indicators Steering Group, Paris.

Akpokodje, G., 1998, 'Macroeconomic policies and private investment in Nigeria', in B.E. Aigbokan (ed.), Rekindling investment for economic development in Nigeria, B.E. Aigbokan (ed.), Rekindling investment for econc
pp. 21-34, The Nigeria Economic Society, Ibadan.

Allen, R.C., 2001, 'The great divergence in European wages and prices from the middle ages to the First World War', Explorations in Economic History 38, 411-447.

Atkeson, A. \& Kehoe, P.J., 2007, 'Modeling the transition to a new economy: Lessons from two technological revolutions', American Economic Review, 97(1), 64-88. https://doi.org/10.1257/aer.97.1.64

Atkinson, A. \& Correa, D., 2007, The 2007 state new economy index. Benchmarking economic transformation in States, Information Technology and Innovation Foundation, Washington, DC.

Audretsch, D.B., Keilbach, M. \& Lehmann, E.E., 2006, Entrepreneurship and economic growth, Oxford University Press, New York, NY.

Awe, O.W., 2010, Entrepreneurship development, 5th edn., YBT Printserve Ventures, Lagos.

Beck, T. \& Levine, R., 2004, 'Stock markets, banks and growth: Panel evidence', Journal of Banking and Finance 28(3), 423-442. https://doi.org/10.1016/S03784266(02)00408-9

Bemelmans-Videc, M.L., 1994, De beleidsevaluatie bij centrale overheden: Ontwikkelingen in Europa, de Verenigde Staten en Canada (Policy Evaluation in Central Governments; Developments in Europe, the U.S.A. and Canada). Central Governments; Developm
Beleidswetenschap, 4, 327-348.

Bergmann, H., Mueller, S. \& Schrettle, T., 2013, 'The use of global entrepreneurship monitor data in academic research: A critical inventory and future potentials', International Journal of Entrepreneurial Venturing 6(3), 1-43. https://doi. org/10.1504/IJEV.2014.064691

Boame, A.K., 1998, 'Primary-export-led growth: The evidence of Ghana', Journal of Economic Development 23(1), 175-194.

Carree, M.A. \& Thurik, A.R., 2002, 'The impact of entrepreneurship on economic growth', in Z.J. Acs \& D.B Audretsch (eds.), Handbook on entrepreneurship research: International handbook series on entrepreneurship 5, pp. 437-471, Science Business Media, Springer.

Cecchetti, S., 2002, The new economy and the challenges for macroeconomic policy, NBER Working Paper Series No. 8935, The National Bureau of Economic Research, Cambridge, MA.

Dehn, J., 2000, Private investment in developing countries: The effect of commodity shocks and uncertainty, Center for the study of African Economics, University of Oxford, Oxford.
Dutt, A.K. \& Ros, J., 2003, Development economics and structuralist macroeconomics: Essays in honor of Lance Taylor, Edward Elgar, Cheltenham.

Economic Community of West African States (ECOWAS), Vision 2020, viewed 18 May 2019, from https://www.ecowas.int/about-ecowas/vision-2020/

Enisan, A.A. \& Olufisayo, A.O., 2009, 'Stock market development and economic growth: Evidence from seven sub-Saharan African countries', Journal of Economics and Business 61(2), 162-171. https://doi.org/10.1016/j.jeconbus.2008.05.001

Ezeoha, A.E., Ogamba, E. \& Onyiuke, N.O., 2009, 'Stock market development and private investment growth in Nigeria', Journal of Sustainable Development in Africa 11(2), 20-35.

Global Entrepreneurship Monitor (GEM), 2010, Global Entrepreneurship Monitor. viewed n.d., from http://www.gemconsortium.org

Greenaway, D. \& Morrissey, O., 1992, 'Structural adjustment and liberalization in developing countries: What lesson have we learned?', Kyklos 46(2), 241-261. developing countries: What lesson have we learned?'
https://doi.org/10.1111/j.1467-6435.1993.tb02423.x

Harrigan, J. \& Mosely, P., 1991, 'Evaluating the impact of World Bank structural adjustment tending', Journal of Development Economics 48, 419-427.

Hindle, K., 2009, 'The relationship between innovation and entrepreneurship: Easy definition, hard policy', Paper delivered to the refereed stream of the 6th AGSE International Entrepreneurship Research Exchange, 3-6 February, Adelaide.

Hopkins, A.G., 1973, An economic history of West Africa, Longman, London.

Hornby, A.S., 2010, Oxford advanced learner's dictionary (8th ed.), Oxford University Press, Oxford, New York.

Huggins, R., Morgan, B. \& Williams, N., 2015, 'Regional entrepreneurship and the evolution of public policy and governance: Evidence from three regions', Journal of Small Business and Enterprise Development 22(3), 473-511.

Ijeoma, E.O., 2014, Introduction to South African's monitoring and evaluation in government. On behalf of Independent Service Delivery Monitoring Networks (ISDMN), Verity Publishers, Pretoria.

Jones, E.L., 1981, The European miracle: Environments, economies and geopolitics in the history of Europe and Asia, Cambridge University Press, Cambridge.

Khan, M.S. \& Reinhart, C., 1990, 'Private investment and economic growth in developing countries', World Development 18(1), 19-27. https://doi. org/10.1016/0305-750X(90)90100-C

Lemi, A. \& Asefa, S., 2001, 'Foreign direct investment and uncertainty: The case of African economies', in Proceedings of the International Business and Economics Research Conference, October 8-12, Reno, NV.

Mayer, I., 2007, 'The evolution of policy analysis in the Netherlands, Chapter 36', in F. Fischer, G.J. Miller. \& M.S. Sidney (eds.), Handbook of public policy analysis: theory, politics, and methods (3rd ed.), pp. 553-570, Taylor \& Francis, New York.

Mccaffrey, M., 2018, 'William Baumol's 'Entrepreneurship: Productive, Unproductive, and Destructive' in G. Javadian, V.K. Gupta, D.K. Dutta, G.C. Guo, A.E. Osorio \& B. Ozkazanc-Pan, (eds.), Foundational Research in Entrepreneurship Studies: B. Ozkazanc-Pan, (eds.), Foundational Research in Entrepreneurship Studies:
Insight Contributions and Future Pathways, pp. 179-201. https://doi. Insightful Contributions and Future
org/10.1007/978-3-319-73528-3_9

Murdock, K.A., 2009, 'Public policy for entrepreneurship and innovation. Trade-offs and impacts in managed and entrepreneurial economies', Unpublished PhD thesis, University of Barcelona, Barcelona.

North, D.C., 1981, Structure and change in economic history, W.W. Norton, New York, NY.

N'Zue, F., 2006, 'Stock market development and economic growth: Evidence from Côte D'Ivoire', African Development Review 18(1), 123-143. https://doi. org/10.1111/j.1467-8268.2006.00135.x

Organisation for Economic Co-operation and Development (OECD), 1998, Efforts and Policies of the Members of the Development Assistance Committee, viewed 06 May 2019, from: https://www.oecd-ilibrary.org/development/development-cooperation-report-1998_dcr-1998-en

Rosenbloom, D.H., Kravchuk, R.S. \& Clerkin, R.M., 2009, Public administration: Understanding management, politics, and law in the public sector (8th ed.), McGraw-Hill International Edition, New York, NY.

Saisana, M. \& Munda, G., 2008, Knowledge economy: Measures and indicators. Working Paper EUR 234BB EN. European Commission Joint Research Centre, Italy.

Schumpeter, J., 1934, The theory of economic development, Harvard University Press, Cambridge, MA.

Serven, L. \& Salimano, A., 1992, 'Private investment and macroeconomic adjustment: A survey', World Bank Research Observer 7(1), 95-114. https://doi.org/10.1093/ wbro/7.1.95

Torres, C. \& Van Seters, J., 2016, Overview of trade and barriers to trade in West Africa: Insights in political economy dynamics, with particular focus on agricultural and food trade, Discussion Paper 195, European Centre for Development Policy Management (ECDPM), Maastricht.

World Development Indicators (WDI), n.d., World Development Indicators, viewed 20 May 2019, from https://databank.worldbank.org/source/world-developmentindicators 